TARNOWSKIE STUDIA TEOLOGICZNE 36 (2017) NR 2, S. 195-199

http://dx.doi.org/10.15633/tst.2624

dk. Grzegorz Wolak

UNIWERSYTET PAPIESKI JANA PAWŁA II W KRAKOWIE

\title{
Patriotyzm - dobrze pojęta miłość Ojczyzny... Sesja naukowa, Tarnów 10 maja 2017 roku
}

10 maja 2017 roku w sali konferencyjnej Małopolskiego Urzędu Wojewódzkiego w Tarnowie odbyła się sesja naukowa pt. Patriotyzm - dobrze pojęta miłość Ojczyzny..., zorganizowana przez biskupa tarnowskiego Andrzeja Jeża oraz starostę tarnowskiego Romana Łucarza. Tym razem poświęcona była właśnie patriotyzmowi i stanowiła próbę poszukiwania odpowiedzi na wiele współczesnych pytań dotyczących pojmowania i praktykowania miłości ojczyzny.

Tematyka bardzo aktualna i niezwykle istotna, jak na wstępie zaznaczył starosta tarnowski. Wśród pytań, które postawił, znalazły się m.in.: „Jaki powinien być dzisiejszy patriotyzm?”, „Na co powinniśmy zwrócić uwagę w naszej miłości ojczyzny?” Współcześnie spotykamy się przede wszystkim z zagadnieniem nowoczesnego patriotyzmu. Pytanie, jakie stawiamy, brzmi zatem: „Co ja mogę zrobić dla ojczyzny?”, zamiast: „Co ojczyna może zrobić dla mnie?”. Starosta w odpowiedzi stwierdził, że patriotyzm jest sumiennym wypełnianiem swoich obowiązków i funkcji oraz troszczeniem się o dobro wspólne. Nowoczesny patriotyzm przejawia się również w pamięci o naszej chrześcijańskiej tożsamości.

Słowo wstępne skierował do słuchaczy bp Andrzej Jeż, który zwrócił uwagę na pewną istotną właściwość postawy patriotycznej Polaków. Mianowicie, możemy mówićo patriotyzmie podniesionym niemalże do rangi religii. Szukając przyczyn tego zjawiska, biskup wspomniał burzliwą, lecz jednocześnie piękną i pełną heroizmu historię Polski. Przypomniał, że Jan Paweł II w 1979 roku w Belwederze doskonale ujął istotę patriotyzmu, mówiąc, że w porównaniu z innymi narodami słowo „ojczyzna” ma dla Polaków wyjątkowe znaczenie uczuciowe i pojęciowe. Następnie opisując zjawisko patriotyzmu, biskup wziął pod uwagę właściwe temu słowu komponenty, takie jak naród, teren, historia, religia, gospodarka itp. Słuchacze zostali również zapoznani 
z dwiema niebezpiecznymi skrajnościami, które mogą być spowodowane niewłaściwym rozumieniem patriotyzmu. Pierwsza z nich to multikulturalizm, który atakuje kulturę narodów. Druga skrajność to postawy szowinistyczno-nacjonalistyczne, w których chęć zdominowania innych jest mocno zakorzeniona w samoświadomości narodu. Biskup zaznaczył, że właściwie rozumiany patriotyzm umożliwia poszanowanie innych narodów i prowadzenie z nimi dialogu. Wśród zarzutów skierowanych w stronę polskiej teologii jest i ten mówiący o zbyt mocnym akcencie położonym na tożsamość narodową. W związku z tym trzeba spojrzeć na postawę Jezusa, który posługiwał się kulturą swojego narodu i z tego wyprowadzał uniwersalne nauczanie o królestwie Bożym. Biskup stwierdził, że - obiektywnie patrząc gdybyśmy chcieli z naszej 1050-letniej tradycji wymazać Kościół, to niewiele by pozostało. Chodzi zatem o to, by myśląc o przyszłości świata, nie pominąć uniwersalności Kościoła, gdyż ona może przezwyciężyć wspomniane już niebezpieczne skrajności. Pomocna w tym będzie również eschatologiczna wizja niebieskiej ojczyzny, do której wszyscy zmierzamy. Podsumowując, stwierdził, że jeśli patriotyzm ma przetrwać, to trzeba o nim mówić.

We wstępie głos zabrał również senator Kazimierz Wiatr, który mówił m.in. o miłości jako praźródle patriotyzmu. - Miłość do ojczyzny ma swoje początki w domu rodzinnym. Rozwija się ona na fundamencie, jakim jest miłości do ojca i matki, i miłości rodziców do dzieci. W domu uczymy się szacunku do przeszłości, do naszych korzeni, równocześnie spoglądając z troską w przyszłość. Profesor wspomniał także, że chrześcijaństwo usposabia nas do postawy pomocniczości i życzliwości wobec innych narodów.

Na zakończenie części wprowadzającej małopolski kurator oświaty Barbara Nowak powiedziała, że patriotyzm skłania nas również do snucia refleksji na temat powinności wobec matki ojczyzny. Zwróciła uwagę na celowe współcześnie rozmywanie tego pojęcia i spychanie go na dalszy plan. Patriota jest dumnym spadkobiercą tradycji chrześcijańskiej państwa polskiego. Jako nauczycielka historii podkreśliła kluczową rolę, jaką pełni szczepienie u młodych pokoleń poczucia dumy narodowej.

Zasadnicza część sesji naukowej została poprowadzona przez ks. Marka Kluza. Poszczególni prelegenci podejmowali rozmaite tematy pozwalające spojrzeć na zjawisko patriotyzmu z różnych stron oraz podejmowali szereg ciekawych zagadnień z nim związanych.

Pierwszy z prelegentów ks. Grzegorz Baran zaprezentował temat $\mathrm{Na}$ ród i ojczyzna $w$ tradycji biblijnej. Treść wykładu zawarta została w trzech 
punktach. Pierwszy dotyczył narodu wybranego i jego ojczyzny. Kapłan przedstawił historię Abrama, który opuścił jedną ojczyznę, aby posiąść drugą. Następnie przytoczona została krótka historia potomków Abrama, aż do dwunastu pokoleń Izraela, które stanowią zasadniczy zrąb narodu wybranego. Najważniejsza myśl tego punktu to Boże prowadzenie narodu izraelskiego i dar w postaci ojczyzny - Ziemi Obiecanej. Dla narodu wybranego pojęcie ojczyzny wiązało się nie z jakimś miejscem - terytorium, lecz z Bogiem. Ten dar ojczyzny był uwarunkowany wiernością wobec Boga. Drugi punkt dotyczył chrześcijańskiej perspektywy pojęcia ojczyzny. Prelegent zaznaczył, że Chrystus ukonstytuował Nowy Izrael, który obejmuje wszystkie narody, ludy i języki. Nasza wspólnota to Kościól, gdzie Chrystus jest kamieniem węgielnym. Od teraz dążymy do tego, co w górze, gdzie jest nasza ojczyzna - niebo. Ostatni punkt oparty był na pytaniu: „Chrześcijanin kosmopolitą czy patriotą?”. Prelegent w oparciu o tekst: „A tu już nie ma Greka ani Żyda, obrzezania ani nieobrzezania, barbarzyńcy, Scyty, niewolnika, wolnego, lecz wszystkim we wszystkich jest Chrystus" (Kol 3, 11), zastanawiał się czy św. Paweł w ten sposób głosił ideę totalnego burzenia istniejącego porządku społecznego. Odpowiedź jest negatywna, gdyż zniwelowanie barier, o których mowa, powinno mieć miejsce na gruncie teologicznym. Nie chodzi zatem o zacieranie tożsamości różnych kultur, ale o niwelowanie wszystkiego, co złe we wzajemnych relacjach. W postawie Jezusa widzimy samoświadomość tożsamości narodowej i przywiązanie do własnego narodu, ale i życzliwe odniesienie do innych ludów. W podsumowaniu prelegent stwierdził, że chrześcijanin winien być w pierwszym rzędzie patriotą. Trzeba patrzeć na naród i ojczyznę w świetle IV przykazania Dekalogu. W Katechizmie Kościoła Katolickiego czytamy, że to przykazanie odnosi się także do ojczyzny. Patriotyzm jest obowiązkiem, nie jest jednak wartością absolutną w wymiarze ziemskim. Do ojczyzny niebieskiej zmierza się przez ojczyznę ziemską.

Kolejny referat, wygłoszony przez Magdalenę Czarnecką z wydawnictwa „Jezu, ufam Tobie”, skupiał się na kwestii języka narodowego. Prelegentka na początku zwróciła uwagę na kontrowersje, jakie budzi patriotyzm. Mianowicie, staje się on często przyczyną niezgody, a przecież powinien łączyć. Uważamy, że w przeszłości łatwiej było być patriotą. Jednak gdy prześledzimy historię, zauważamy, że sprawa nie jest tak oczywista, biorąc pod uwage chociażby czasy zaborów. W spomniany okres w dziejach narodu był czasem zmagania się m.in. z rusyfikacją i germanizacją. Na tym właśnie przykładzie 
możemy dotknąć zasadniczej treści wykładu, gdyż walka o język narodowy była wówczas stawiana na równi z walką wyzwoleńczą. Młode pokolenia Polaków nie potrafią zrozumieć nacisku na dbałość o język polski, gdyż doświadczenia z okresu zaborów są dla nich jedynie encyklopedyczną notką historyczną. Nie doświadczyli natomiast walki w obronie własnej tożsamości narodowej niejednokrotnie opłaconej ceną własnej krwi. Prelegentka przedstawiła również krótką historię naszego języka ojczystego i jego rozwój na przestrzeni wieków. Wniosek końcowy wskazuje, że dbałość o język staje się wyrazem patriotyzmu, a więc jest powinnością. Wśród negatywnych zjawisk, jakie napotykamy w kulturze języka, prelegentka wymieniła dwa zasadnicze: wulgaryzmy oraz zapożyczenia. Podsumowując, stwierdziła, że Bóg stworzył świat właśnie przez Słowo. Kościół jest, albo przynajmniej powinien być, miejscem dbałości o polską sprawę. Stąd ważne, aby kapłani szczególnie dbali o poprawność językową.

Martyna Deszczyńska z Biblioteki Narodowej w Warszawie wygłosiła referat pt. Pamięć historyczna źródłem patriotyzmu. Kluczowe pytanie brzmiało: "Jakie jest znaczenie znajomości historii w budowaniu patriotyzmu?”. Prelegentka zwróciła uwagę na problem pamięci międzypokoleniowej oraz tendencje mass mediów do kształtowania pamięci historycznej. Trzy kluczowe pojęcia, które należy rozróżnić to: świadomość historyczna, pamięć historyczna oraz wiedza historyczna. Pierwsze dwa są dziś dość dobrze zdefiniowane. Prelegentka uważa, że patriotyzm jest fenomenem społecznym, który podlega zjawisku odczuwania. Zagadnienie wspólnoty wydaje się fundamentalne $\mathrm{w}$ definicji patriotyzmu. Ludzie mają dzisiaj problem z określeniem własnej tożsamości, i to na różnych jej poziomach - społecznej, jednostkowej, kulturowej, lokalnej itd.

Rzetelna wiedza historyczna pomaga $\mathrm{w}$ budowaniu tożsamości patriotycznej. W podsumowaniu prelegentka stwierdziła, że historia jest swego rodzaju łącznikiem pomiędzy wolą pokoleń przeszłych i obecnych. Nauczyciele, rodzice i wychowawcy są odpowiedzialni za krzewienie postaw patriotycznych.

Kolejny referat, wygłoszony przez ks. Norberta Mojżyna z UKsw, obejmował zagadnienie kultury jako nośnika patriotyzmu. Na początku prelegent przedstawił krótką historię sztuki w Polsce. Całość wystąpienia była zbudowana w oparciu o prezentację multimedialną, dzięki której patrząc na kolejne obrazy, można było w krótki i przystępny sposób poznać najważniejsze elementy sztuki patriotycznej w historii naszego narodu. Prelegent 
skonstatował, że kultura ma tak istotny wpływ na świadomość patriotyczną, że nie można się od niej izolować. Kardynał Stefan Wyszyński powiedział kiedyś, że człowiek, który odcina się od kultury, skazuje się dobrowolnie na śmierć.

Podsumowaniem sesji było wystąpienie ks. Janusza Królikowskiego poświęcone tematowi: Patriotyzm między przeszłością i przyszłością. Prelegent, powołując się na referat ks. Twardowskiego skierowany do żołnierzy, mówił, że patriotyzm jest trudny do zrozumienia. Dzieje się tak dlatego, że jest to postawa, która domaga się odpowiedniego ukształtowania umysłu i serca. Kształtowanie umysłu jest zdecydowanie prostsze niż formacja serca. Warto jednak ciągle na nowo zastanawiać się nad istotą pojęcia „ojczyzna” i tym, co się na nie składa oraz nad sposobami osobistego i wspólnotowego odniesienia do tych podstawowych rzeczywistości, którymi są: wspólne terytorium, wspólny język, wspólne instytucje społeczno-polityczne oraz wspólna pamięć. W tych dziedzinach pragniemy szukać dobrze pojętej miłości ojczyzny.

Reasumując, omawiana sesja naukowa pozwoliła na głębsze spojrzenie na rzeczywistość, jaką jest patriotyzm, a szczególnie jego współczesne formy. Przedstawione przez prelegentów zagadnienia stanowiły swego rodzaju odpowiedź na słowa ks. bp. Andrzeja Jeża. Mianowicie, że jeśli patriotyzm ma przetrwać, to trzeba o nim mówić, a podczas tej sesji powiedziano o nim wiele. 